UDC 007:659.4

DOI https://doi.org/10.32841/2409-1154.2021.47-2.13

\author{
Pavlova O. O., \\ Associate Professor at the Department of Philology, Translation and Strategic Communications \\ National Academy of the National Guard of Ukraine
}

\title{
DIRECTIONS OF PUBLIC RELATIONS TECHNOLOGIES OF THE NATIONAL GUARD IN UKRAINE
}

Summary.Thearticledefinestheneedtoestablishanddevelop PR institute of the National Guard as an essential attribute of a democratic society. PR is observed as multicomponent and multidimensional system of communication. The systemic transformation and democratization of Ukrainian society is leading to the mainstreaming of communicative aspects of the National Guard activities. It is a subject of paramount importance, forming the basis for the actions of the National Guard. Public Relations development of the power structure makes it possible to provide an effective mechanism for addressing the many challenges faced by the National Guard, to eliminate the barriers in the communication process between the National Guard and the public. In a democratic society, the Army Public Relations play system-building and integrative role, PR techniques ensure that the best possible decisions are made. PR technologies application makes it possible to develop democratic civilian control of the National Guard, contributes successfully to the affirmation and development of the civil society and to facilitate optimization of information flows, to foster a closer cooperation and collaboration between the public and power structure. Generating positive political image of the National Guard is one of the priority PR goals, thus ensuring the legitimization of power structure functioning, the strategic policy support of the National Guard by both the Ukrainian public and the international community.

The experience of PR in the western armies is analyzed; PR directions and tasks of the National Guard in Ukraine are discovered and cleared in the article. When considering PR as a communicative-psychological organization's engagement with the community, centered on the model of compromise, the basic functions of Public Relations in the National Guard (informative, informing-expressional, communicative, integration-communicative, socializing, organizational and behavioural, prognostic, protective functions) are defined in the article. The paper clarified that PR strategies of the National Guard would depend largely on the forethought and planning of tactical supporting, based on combination of interconnected and coherent PR technologies, including policy and institutional, informational and procedural technological sustained action, aimed at the realization of the image-building PR strategy of the National Guard.

Key words: Public Relations, civil-military relations, National Guard image, PR technologies, PR strategy, communication system.

Formulation of the problem. The development of Ukraine as a democratic and social State that respects rights and justice, a foreign policy aimed at moving closer to Western Europe, integration processes provide for defense reform, focused on restructuring and transformation of the National Guard in the country; a gradual convergence of security agencies according to Western European and global standards; the establishment of an institution, that society can access and understand and in all situations is monitored by it, acting in its purpose and structure under the Constitution and the laws of Ukraine. Moreover, the strengthening of the democratic foundations of society requires a new paradigm in interacting between security forces and the community, the attainment of civilian-military relations streamlining and harmonizing, the implementation an entirely new system of relations between the National Guard and the public, based on trust and behaviour patterns of cooperation and reconciliation of interests, transparency and understanding, constructive social supervision and criticism. The priorities, implementing such requirements include more openness of the structure, the intensification of information and communication policy, the introduction of new contact forms with population, the creation of institutions for democratic civilian control of the National Guard, which embodies the commonly recognized model of civilianmilitary relations and defines military strategy subordination to the civil authority.

Nowadays optimum civil-military cooperation is a guarantee for political stability and safety of the country, strengthening society, it is an aspect of the democratic development and consolidation of State authority, the political recognition of Ukraine as a sovereign State in the international arena and necessary condition for integration into European and transatlantic structures.

Therefore, the problem of civilian-military relations democratization is especially relevant and has political significance today. In that context, the question arose as to find and apply efficient mechanisms for the implementation of optimization strategies and democratization of the military and civilian branches.

To meet these goals, it would be appropriate to apply the methods and technologies of communicative system of Public Relations (PR), which are innovative for the National Guard in Ukraine and are considered as an effective tool for civilian-military relations regulation as well as a matter of better relations between the power structure and community. As a communicative-psychological interaction of the National Guard with civilian population, Public Relations provide public recognition, support of citizens, grants credibility to the National Guard, contribute to a shared understanding and balanced military policy with social interests, provide the legitimacy of the National Guard activities through positive political image of the structure. Professionally developed image of the National Guard, in the absence of direct contact of the public with the National Guard, becomes a form of reflection of the structure in citizens' conscience, captures its essence in a concentrated form, has emotional and psychological impact on community. By providing positive perception of the National Guard in a society, by developing confidence in the structure, the positive image is becoming a factor of the National Guard legitimization. 
Its development should therefore be a high priority of PR strategy of the National Guard.

Given the relevance and insufficient scientific findings of the question, the aim of this article is to comprehensive study of Public Relations of the National Guard in Ukraine as a multidimensional system of communications of the structure and the community. The directions of Public Relations technologies of the National Guard based on summaries of the experience concerning development and the functioning of public relation institutions of security forces of democratic nations are highlighted in the article.

Analysis of actual researches. The problem of democratization and streamlining of civilian-military relations through a wider use of Public Relations technologies has not been the subject of special politological studies. It should be noted the lack of development of the given problem, the deficiency of objective, scientific operating model of Public Relations institution of the National Guard in Ukraine. The question concerning the role of information and communication units of the National Guard in the implementation of PR strategy, the building collaboration with the media and image generating of the National Guard have not been fully highlighted.

The effectiveness and efficiency of Army Public Relations in countries such as the United States, Canada, Britain, Germany, France, Sweden, Turkey, Japan is supported by a high rating of public confidence in the militaries, the optimization and the democratization of civilian-military relations, developed civilian control over the military, stable positive image of army, the prestige of military professions.

The analysis of experience with the effective and efficient functioning of Public Relations institution in the armies of democratic States has shown that this practice should be more extensively considered and implemented.

It should be emphasized that little research has been done to the issue of formation and development of Army Public Relations in national science. There are no robust research on the problem, which would highlight clearly and comprehensively the conceptual, categorical and technological bases of Army Public Relations.

Some theoretical and methodological aspects of the issue have been presented in the studies of the following authors: A. Litvinenko, H. Pocheptsov, V. Korolko, L. Leontieva, H. Tykhomirova, V. Bebik. However, the topic was not comprehensively covered, there is no systematic approach using a harmonized methodology in these works.

Presentation of the main material. Army Public Relations is a new form to ensure the relationships between Ukrainian Army and the community, appropriate for principles of contemporary democracy. It should be observed, however, that the development of Army Public Relations Institution is rather a slow process. This is due to the little experience; some concerns about raising public awareness of the topical issues, problems and crisis situations; the peculiarities of the political culture, including certain exclusion of society from policy; as well as insufficient civil society maturity and the consequent lack of demand for a well-developed system of Army Public Relations. Experts note that it is a development of a civil society requires creating backward and forward linkages between the power structures and the community.

"Public Relations" is an essential to democracy and constituted the basis for sustainable development as well as an important component of communication policy of Armed Forces in Western societies and in democratic societies around the world. The political and military authorities of Great Britain, the USA, Canada, Germany, France, and Japan ensure maximum development of relationships among army and the community and undertake a major effort to involve the public in the discussion of military issues as widely as possible, as appropriate.

Particularly much attention is given to the maintaining military contacts with the public in the military bases. To that end, it uses such events as invitations of civilian population to participate in the commemoration of important historical events. They conduct large-scale initiatives for children, adolescents and young people; issue a lot of books, leaflets or booklets; distribute souvenirs, posters, calendars, badges etc. Military parades, military orchestras, military-sports competitions, demonstration of equipment and weapons, flights on helicopters or planes have become traditional events in the USA, Great Britain, France, Germany. The Government of Japan invites local people to take part in military maneuvers and exercises of 'self-defense forces'. The military commander carries out "open days" on a regular basis to engage civil society in real army life in many Western countries. Positive image development of the German armed forces is an area of central concern for certain categories of officers. Their functional responsibilities include the systematic school visits, interviewing young people, the clarification of the strategic orientations of military policy and improving the ability and motivation for military service [10, p. 14].

Some experts, practitioners and leading academics in this field determine the concept of "Public Relations" as follows:

1) management activity, which aims to establish a mutually beneficial relationship between organization and the public, on which the success of this organization depends;

2) establishing two-way communication channel in support of the overall vision and common interest, in order to advance common understanding, based on truth, knowledge and full public disclosure;

3 ) encouraging people to trust in corporation's honest goals, demonstration of how corporations build confidence and trust with the community;

4) specialized and professionally organized public opinion control in a specific field; to corporate relations, exercised not by command and control methods.

These definitions clearly indicate that "Public Relations" is a specific kind of managerial performance, aimed at creating a favorable environment for two-way communications and positive attitude towards organization's activities, harmonization and alignment in their interests. Indeed, that is the main characteristics of any PR-activity [1, p. 6].

The researchers have given the following definitions of "Army Public Relations":

- it is a system of info-analytic and procedure-technological actions to organize or encourage optimal communicative space for the establishment and maintenance of positive image of power department, democratic civilian control of the defense and security forces and harmonization of Defense Ministry policy with the public interest;

- it is established communicative and psychological collaboration between structure and community in a suitable informationalenvironmentforinteraction, theskillofbuildingmutually 
beneficial relationships between security forces and the population to benefit society as a whole;

- particular control function, which is the analysis and examination of the public perceptions and public opinion research, which is promoting the action programme, aimed at balancing the interests involved (civil-military relations), a better understanding of the existing conflicts in this area, forecasting of conflicts and establishment of a two-way communication channel [8, p. 332-336].

PR experts have allocated the following key stages of PR strategy building:

- an analytical review (the situation regarding key objectives of the structure, involving communication activities of competitors);

- the formulation of strategic and tactical goals and objectives of the structure;

- focus group, included task groups and subgroups;

- communication channels, considering coverage of the focus group and effectiveness;

- PR technologies and forms of promotion, according to the most efficient and effective influence on the focus group;

- basic messages;

- communication plan for a certain period, which includes the schedule, frequency and budget making;

- projection results and performance indicators.

PR strategies of the National Guard would depend largely on the forethought and planning of tactical supporting, based on combination of interconnected and coherent PR technologies, including policy and institutional, informational and procedural technological sustained action, aimed at the realization of the imagebuilding PR strategy of the National Guard.

Taking into consideration that, PR system of the National Guard comprises the following levels of communicative influence on public opinion - event communication verbal communication, nonverbal communication, accordingly and it is possible to categorize the main PR technologies based on the exercise of image characteristics that they provide.

According to L. Klimanska, the basic characteristics and special features of image are provided through verbal, nonverbal and event projections. This approach to classification system of PR technologies of the image have also resulted in a structure of this subsection, which dealt successively with three groups of PR technologies in the context of providing the projections (verbal, nonverbal and event) of the National Guard image [4].

Performance PR Technology ensures the realization of image characteristics through event projection. The essence of this technology consists in targeted events-creating, PR campaigns, activities, indicating positive image characteristics. For instance, military rituals and traditions as special types of performance are important in the development of positive public opinion of the National Guard.

PR-technologies of image characteristics visualization is the most effective way of providing nonverbal image projection, which are to translate the image characteristics of the National Guard into the language of visual patterns and symbols with the application of the following visual aids: television, theatrical, content production, photographic coverage of the National Guard activities, television and radio broadcasts, posters, stickers, leaflets, brochures, military symbols and so forth. Advertisement is an efficient and effective way to provide image characteristics visualization. It is in the advertising materials that the visual patterns and symbols are the main means of the transmission of the image characteristics, key messages and ideas.

Verbal image projection involves image characteristics realizing of the National Guard by means of verbal symbols and signs, spoken and written language. Image verbalization is mainly given expression in PR-texts of various genres (the creation of these texts is a high priority for the information-communicative subsection of the National Guard), as well as in advertising texts.

Political-psychological PR-contrast strategy is a particular group of PR technologies (comparison with competitors and similarities and accession to the image of authoritative object.

The image development according to social expectations is one of the effective and promising political-psychological PR-technologies, providing a comprehensive analysis of the target group's social expectations, perceptions and requirements for a perfect image of power structure and creating an image based on this analysis. Compliance of the National Guard image with the public interests is one of the major factors influencing its effectiveness and credibility. However, changing the interests, needs, expectations of the target group requires appropriate and active correction of the National Guard.

An important place in the image PR-strategy of the National Guard is held by technologies of image protection, which provide for early and effective opportunities for positive interpretations for questionable or negative aspects of the National Guard activities and operations. In such cases, it might be useful to perform the preventive and preemptive activities.

When considering PR as a communicative-psychological organization's engagement with the community, centered on the model of compromise, it is possible to define the basic functions of Public Relations in the National Guard.

In accordance with the above-mentioned material, the following functions are considered as priorities:

- informative function is to provide complete accurate, impartial, comprehensive, balanced, coherent, timely and relevant information on the activities of the structure; the creation of a single system to receive and send to communications);

- informing-expressional function involves the provision of assessment, emotionally charged information);

- communicative function consists of providing the cooperation and information-sharing mechanisms between the public and the National Guard;

- integration-communicative function includes the forming a common understanding and emotional-psychological attitude of the target group;

- socializing function is to develop or change the social and political attitudes regarding the National Guard, to define common value perspectives of the population;

- organizational and behavioural (pragmatic function) is to serve as a stimulation of concrete actions of the target group in a certain direction, as well as initiation, termination or modification. This function also covers the achievement of public confidence, the encouragement of the community to make certain decisions and to respond in a particular way;

- prognostic function focuses on forecasting trends in the development of the relationship between the National Guard and the public, foreseeing the changing orientations of the target groups, their attitudes and values. The timely forecasting enables 
PR departments to lay out the strategic orientations of the National Guard information policy, to prevent undesirable public responses and actions;

- protective function protects the interests of the National Guard and the public. This result is achieved due to the public opinion monitoring and well-functioning feedback, conducted by PR experts.

The above-mentioned Public Relations functions in the National Guard in Ukraine are intended to provide the most fundamental function implementation, which may be defined as a function of social relations harmonization, two-way communication development, mutual understanding, mutual recognition and multilateral cooperation; the development of positive political image of the National Guard by providing information on and PR events intended to shape public opinion.

Conclusions and perspectives of further research. The systemic transformation and democratization of Ukrainian society is leading to the mainstreaming of communicative aspects of the National Guard activities. This is a subject of paramount importance and forms the basis for the actions of the National Guard. Public Relations development of the power structure makes it possible to provide an effective mechanism for addressing the many challenges faced by the National Guard, to eliminate the barriers in the communication between the National Guard and the public. In a democratic society, the Army Public Relations play systembuilding and integrative role, PR techniques ensure that the best possible decisions are made.

PR technologies application makes it possible to develop democratic civilian control of the National Guard, contributes successfully to the affirmation and development of the civil society and to facilitate optimization of information flows, fosters a closer cooperation and collaboration between the public and power structure. Generating positive political image of the National Guard is one of the priority PR goals, thus ensuring the legitimization of power structure functioning, the strategic policy support of the National Guard by both the Ukrainian public and the international community.

\section{References:}

1. Богданов Е.Н., Зазыкин В.Г. Психологические основы «Паблик рилейшнз». 2-е изд. Санкт-Петербург : Питер, 2003. 203 с.

2. Богуславський О.В., Горевалов С.І., Романишин Ю.А. Військова преса України. Запоріжжя, 2004. 479 с.

3. Грушевський Д.О. Спеціальні інформаційні операції та інформаційні війни в сучасному світі (досвід Афганістану). Актуальні проблеми міжнародних відносин. 2001. Вип. 28. Ч. 1. С. 277-289.

4. Литвиненко О.В. Інформаційні війни та формування системи протидії: випадок України. Актуальні проблеми міжнародних відносин. 2000. Вип. 18. Ч. 1. С. 220-226.

5. Требін М. Армія і суспільство. Взаємодія в умовах трансформації. Віче. 2001. № 2(107).

6. Fisher C. Ten shades of truth: A study of Australian journalists' shift to political PR. Public Relations Review. 2016. Vol. 42. № 4. P. 665-672.
7. Fredrikssona M., Pallas J. Much ado about media: Public relations in public agencies in the wake of managerialism. Public Relations Review. 2016. Vol. 42. № 4. P. 600-606.

8. Myers M.C., Lariscy R.W. Commercial speech, protected speech, and political public relations. Public Relations Review. 2013. Vol. 39. № 4. P. 332-336.

9. Painter D.L. Online political public relations and trust. Public Relations Review. 2015. Vol. 41. № 5. P. 801-808.

10. Strömbäck J., Kiousis S. Political Public Relations: Old Practice, New Theory Building. Public Relations Journal. 2013. Vol. 7. № 4. P. 3-20.

Павлова О. О. Напрями піар-технологій Національної гвардії України

Анотація. У статті обгрунтовується необхідність становлення та розвитку інституту паблік рилейшнз Національної гвардії України як елементу демократичної правової держави. Паблік рилейшнз розглядається як складна й поліаспектна система комунікацій. У статті наголошується на тому, що в умовах системної трансформації та демократизації українського суспільства актуалізація комунікативного аспекту діяльності Національної гвардії України набуває першочергового значення та становить основу іiї функціонування. Розвиток системи відносин силової структури 3 громадськістю дає змогу сформувати дієвий механізм щодо розв'язання багатьох проблем, подолати відчуженість між Національною гвардією України та цивільним населенням. У демократичному суспільстві паблік рилейшнз (PR) Збройних Сил України відіграє системоутворюючу та інтегративну роль, механізми PR забезпечують прийняття оптимальних політичних рішень. Застосування PR-технологій забезпечує створення системи демократичного цивільного контролю над силовою структурою, сприяє становленню й розвитку громадянського суспільства та оптимізації інформаційної взаємодії між населенням і Національною гвардією України. Реалізація однієї з пріоритетних PR-цілей - формування позитивного політичного іміджу - забезпечує легітимацію функціонування силової структури, підтримку стратегічного курсу Національної гвардії України як громадськістю України, так і міжнародним співтовариством.

У статті проводиться аналіз PR-технологій в арміях західних країн. Сформульовані головні напрями та завдання паблік рилейшнз Національної гвардії України (інформативна, інформаційно-експресивна, комунікативна, інтеграційно-комунікативна, соціалізуюча, організаційно-поведінкова, прогностична, захисна функції). У статті наголошується на тому, що PR-стратегії Національної гвардії України значною мірою залежать від продуманості та спланованості тактичного забезпечення, основу якого становить сукупність взаємопов'язаних та узгоджених PR-технологій - політико-організаційних, інформаційних i процедурно-технологічних послідовних дій, спрямованих на реалізацію іміджевої PR-стратегії Національної гвардії України.

Ключові слова: паблік рилейшнз, цивільно-військові відносини, імідж Національної гвардії України, PR-технології, PR-стратегія, система комунікацій. 